\title{
Petrotoga halophila sp. nov., a thermophilic, moderately halophilic, fermentative bacterium isolated from an offshore oil well in Congo
}

Correspondence
Bernard Ollivier
ollivier@esil.univ-mrs.fr

\author{
Elizabeth Miranda-Tello, ${ }^{1,2}$ Marie-Laure Fardeau, ${ }^{1}$ Catherine Joulian, ${ }^{1,3}$ \\ Michel Magot, ${ }^{4}$ Pierre Thomas, ${ }^{1}$ Jean-Luc Tholozan ${ }^{1}$ and Bernard Ollivier ${ }^{1}$ \\ ${ }^{1}$ IRD, UMR 180, IFR-BAIM, Universités de Provence et de la Méditerranée, ESIL case 925, \\ ${ }^{2}$ El Colegio de la Frontera Sur, Unidad Chetumal, Departamento de Biotecnología Ambiental, \\ Ecología Microbiana Aplicada y Contaminación, Av. del Centenario km 5.5, Col. Calderitas, \\ CP 77900, Chetumal, Quintana Roo, Mexico \\ ${ }^{3}$ BRGM, Environment and Process Division, Biotechnology Unit, BP 36009, F-45060 Orléans, \\ France \\ ¿Université de Pau et des Pays de l'Adour, Laboratoire d'Ecologie Moléculaire EA3525, \\ F-64013 Pau, France
}

Members of the order Thermotogales (e.g. Thermotoga, Geotoga and Petrogoga species), considered as exclusively thermophilic micro-organisms, are known as common inhabitants of petroleum reservoirs (Magot et al., 2000; Ollivier \& Cayol, 2005). Their occurrence within the oilfield environment was established in the 1990s by Stetter et al. (1993) and Davey et al. (1993). However, in contrast to Thermotoga species, which have been isolated from various hot ecosystems throughout the world (e.g. thermal springs, hydrothermal vents), Geotoga and Petrotoga species have been found only in oil reservoirs (Ollivier \& Cayol, 2005). In this respect, it has been suggested that members of the latter two genera might represent typical indigenous micro-organisms in this particular subterrestrial ecosystem (Ollivier \& Cayol, 2005). Two Geotoga species and five Petrotoga species have been characterized so far. The genus Petrotoga comprises Petrotoga miotherma, P. mobilis, P.

The GenBank/EMBL/DDBJ accession number for the 16S rRNA gene sequence of strain MET-B ${ }^{\top}$ is $A Y 800102$. olearia and $P$. sibirica, which originated from brines obtained from petroleum reservoirs located in Oklahoma and Texas (Davey et al., 1993), a North Sea oil-production well (Lien et al., 1998) and a continental petroleum reservoir in Western Siberia ( $P$. olearia and P. sibirica; L'Haridon et al., 2002), respectively. More recently, Petrotoga mexicana was recovered from an oil reservoir in the Gulf of Mexico (Miranda-Tello et al., 2004).

Here we report on the isolation and characterization of a novel bacterial strain $\left(\mathrm{MET}-\mathrm{B}^{\mathrm{T}}\right)$, isolated from an offshore oil well in Africa. Although this strain is phylogenetically closely related to the five species of the genus Petrotoga, it exhibits significant phenotypic and genetic differences that are consistent with its placement within a novel species.

Strain MET-B ${ }^{\mathrm{T}}$ was isolated from an oil/water mixture collected from well TBM111 of the Tchibouella oilfield (Congo). The oil produced was slightly biodegraded, with 
selective and complete removal of the n-alkanes (Connan et al., 1996), and the in-situ temperature and $\mathrm{NaCl}$ concentration were $45^{\circ} \mathrm{C}$ and $98 \mathrm{~g} \mathrm{l}^{-1}$. The samples were collected in sterile glass bottles and kept at $4{ }^{\circ} \mathrm{C}$ until use. $P$. miotherma ATCC $51224^{\mathrm{T}}$ was obtained from the American Type Culture Collection (Manassas, VA, USA). P. olearia DSM $13574^{\mathrm{T}}$ was obtained from the Institut Universitaire Européen de la Mer (Plouzané, France) and P. mexicana DSM $14811^{\mathrm{T}}$ was obtained from our culture collection in Marseille.

The enrichment culture was performed in $60 \mathrm{ml}$ serum bottles inoculated with $2 \mathrm{ml}$ sample. The medium contained the following $\left(\mathrm{l}^{-1}\right.$ distilled water): $0.2 \mathrm{~g} \mathrm{NH}_{4} \mathrm{Cl}, 0.3 \mathrm{~g}$ $\mathrm{K}_{2} \mathrm{HPO}_{4}, 0.3 \mathrm{~g} \mathrm{KH}_{2} \mathrm{PO}_{4}, 0.1 \mathrm{~g} \mathrm{KCl}, 0.1 \mathrm{~g} \mathrm{CaCl} 2,0.5 \mathrm{~g}$ $\mathrm{MgCl}_{2} \cdot 6 \mathrm{H}_{2} \mathrm{O}, 90 \mathrm{~g} \mathrm{NaCl}$ and $10 \mathrm{ml}$ trace mineral element solution (Balch et al., 1979). The $\mathrm{pH}$ was adjusted to 7 with $10 \mathrm{M} \mathrm{KOH}$. The medium was boiled under a stream of $\mathrm{O}_{2^{-}}$ free $\mathrm{N}_{2}$ gas; $20 \mathrm{ml}$ was dispensed into serum bottles under a stream of $\mathrm{N}_{2} / \mathrm{CO}_{2}(80: 20, \mathrm{v} / \mathrm{v})$ gas, and the sealed vessels were autoclaved for $45 \mathrm{~min}$ at $110^{\circ} \mathrm{C}$. Prior to inoculation, yeast extract, potassium nitrate and sodium acetate were injected from sterile stock solutions to final concentrations of $1 \mathrm{~g} \mathrm{l}^{-1}, 10 \mathrm{mM}$ and $20 \mathrm{mM}$, respectively. The bottles were incubated at $50{ }^{\circ} \mathrm{C}$ in a controlled-temperature incubator and three enrichment series were performed in the same medium before isolation. The strain was isolated by repeated use of the Hungate roll-tube technique (Hungate, 1969), using medium solidified with $0.8 \%$ Phytagel (Difco). The process of serial dilution in roll tubes was repeated at least twice in order to purify the cultures.

Growth experiments were performed in duplicate, using Hungate tubes containing basal medium. The basal medium was the same as the enrichment medium but without potassium nitrate or sodium acetate and with $0.2 \%$ yeast extract.

The $\mathrm{pH}$, temperature and $\mathrm{NaCl}$ concentration ranges for growth were determined using basal medium supplemented with $20 \mathrm{mM}$ glucose. The $\mathrm{pH}$ of the medium was adjusted by injecting aliquots of anaerobic stock solutions of $1 \mathrm{M}$ $\mathrm{HCl}$ (acidic pH), $10 \% \mathrm{NaHCO}_{3}$ or $\mathrm{Na}_{2} \mathrm{CO}_{3}$ (basic pH) into Hungate tubes. Water baths were used to obtain incubation temperatures ranging from 37 to $70^{\circ} \mathrm{C}$. To study $\mathrm{NaCl}$ requirements, $\mathrm{NaCl}$ was weighed directly in the tubes before the medium was dispensed. The strain was subcultured under the same experimental conditions before determination of the growth rate. Each substrate was tested in basal medium at a final concentration of $20 \mathrm{mM}$, except for starch and xylan $\left(10 \mathrm{~g} \mathrm{l}^{-1}\right)$. Elemental sulfur $(1 \%$, w/v), sulfate $(20 \mathrm{mM})$, thiosulfate $(20 \mathrm{mM})$, sulfite $(2 \mathrm{mM})$, nitrate $(10 \mathrm{mM})$ and nitrite $(2 \mathrm{mM})$ were tested as terminal electron acceptors. $\mathrm{H}_{2} \mathrm{~S}$ production was determined photometrically as colloidal CuS by using the method of CordRuwisch (1985). Nitrate reduction was evaluated in the absence of ammonium chloride in the culture medium by measuring ammonium or nitrite production. The sensitivity of strain MET- $^{\mathrm{T}}$ to chloramphenicol, kanamycin, rifampicin and vancomycin was tested at 10, 25, 50 and $100 \mu \mathrm{g} \mathrm{ml}^{-1}$. Controls containing ethanol and DMSO (solvents for chloramphenicol and rifampicin) were included. Growth was monitored by measuring $\mathrm{OD}_{580}$ values and by making microscopic observations. Morphological characteristics and purity were observed with an Optiphot (Nikon) phase-contrast microscope. For transmission electron microscopy studies, cell preparations were negatively stained with sodium phosphotungstate, as described by Fardeau et al. (1997). Throughout the analytical studies, duplicate culture tubes were used. Analytical techniques were performed as described by Miranda-Tello et al. (2004). The effect of $\mathrm{O}_{2}$ on growth was determined in Hungate tubes containing anaerobic basal medium supplemented with $20 \mathrm{mM}$ glucose. Tubes were inoculated and various amounts of sterile air were added to the gas phase. The cultures were incubated at $55^{\circ} \mathrm{C}$ with agitation at 150 r.p.m. Growth was monitored using turbidity measurements $(580 \mathrm{~nm})$ and microscopic observations. All of the experiments were conducted in duplicate and were repeated at least twice. The presence of spores was checked using microscopic observation of cultures and pasteurization tests performed at 80,90 and $100{ }^{\circ} \mathrm{C}$ for 10 and $20 \mathrm{~min}$.

The $\mathrm{G}+\mathrm{C}$ content of the DNA was determined at the Deutsche Sammlung von Mikroorganismen und Zellkulturen GmbH (DSMZ) (Braunschweig, Germany), using HPLC as described by Mesbah et al. (1989).

Genomic DNA of strain MET-B ${ }^{T}$ was extracted with the Wizard Genomic DNA purification kit (Promega), and the small-subunit rRNA gene (positions 8-1492, Escherichia coli numbering) was PCR-amplified (30 cycles) with the eubacteria-specific primers 8F (5' -AGAGTTTGATCCTGGCTCAG-3') and 1492R (5'-GTCGTAACAAGGTAACCGTA-3'), as described previously (Thabet et al., 2004). The PCR product was purified (Nucleo Spin Extract kit; Macherey Nagel) and cloned using the pGEM-T-easy cloning kit (Promega). A plasmid containing an insert of the correct length was purified with the Wizard Plus SV Minipreps DNA purification system (Promega). The inserts of three plasmids obtained from independent cloning experiments were sequenced by Genome Express (Grenoble, France) using primers targeting the vector. The smallsubunit rRNA gene sequence of strain MET- $\mathrm{B}^{\mathrm{T}}$ and reference sequences available in GenBank (Benson et al., 1999) were aligned using the sequence-aligner software from Ribosomal Database Project II (Maidak et al., 2001) and the sequence alignment editor BioEdit (Hall, 1999). Phylogenetic analyses were conducted using programs implemented in the TREECON package (Van de Peer \& De Wachter, 1994). Pairwise evolutionary distances of 1248 unambiguous nucleotides were computed using the method of Jukes \& Cantor (1969). A phylogenetic tree was constructed using the neighbourjoining method (Saito \& Nei, 1987). The robustness of the tree topology was tested by a bootstrap analysis involving 1000 resamplings (Felsenstein, 1985). 
DNA-DNA hybridizations were performed at the DSMZ, as described previously (Miranda-Tello et al., 2004).

Enrichment cultures were incubated at $50{ }^{\circ} \mathrm{C}$ for 2 weeks. Microscopic examination of the enrichment culture revealed the presence of rods with an outer sheath-like structure (toga). Circular, white colonies that were $2.0 \mathrm{~mm}$ in diameter appeared after 1 week incubation in roll tubes at $50{ }^{\circ} \mathrm{C}$. Several non-motile strains similar in morphology, unable to reduce thiosulfate and producing the same endproducts of glucose metabolism were isolated, but only strain MET- $\mathrm{B}^{\mathrm{T}}$ was characterized further. The cells were $0.5-0.7 \mu \mathrm{m}$ in width and $2-45 \mu \mathrm{m}$ in length and occurred singly or in sheaths containing up to five cells (data not shown). The cells were not motile and no spore formation was detected. Electron microscopy of thin sections of strain MET-B ${ }^{\mathrm{T}}$ revealed a typical toga cell-wall ultrastructure with a spongy periplasmic layer (data not shown). The cells stained Gram-negative. Strain MET- ${ }^{\mathrm{T}}$ was thermophilic and grew at temperatures ranging from 45 to $65^{\circ} \mathrm{C}$, with an optimum at $60^{\circ} \mathrm{C}$. The isolate was moderately halophilic and grew in the presence of $\mathrm{NaCl}$ concentrations ranging from 5 to $90 \mathrm{~g} \mathrm{l}^{-1}$, with an optimum between 40 and $60 \mathrm{~g} \mathrm{l}^{-1}$. The optimum $\mathrm{pH}$ range for growth was 6.7-7.2 and growth occurred between $\mathrm{pH} 5.6$ and 7.8. Strain MET$\mathrm{B}^{\mathrm{T}}$ fermented D-arabinose, cellobiose, fructose, galactose, glucose, lactose, maltose, L-rhamnose, D-ribose, starch, sucrose, D-xylose, xylan and pyruvate. Glucose was fermented into acetate, lactate, L-alanine, $\mathrm{H}_{2}$ and $\mathrm{CO}_{2}$. No $\mathrm{L}$-alanine was detected when strain MET- $\mathrm{B}^{\mathrm{T}}$ was cultivated in the presence of elemental sulfur as the terminal electron acceptor. The following substrates were not used: acetate, fumarate, succinate, mannose, raffinose, methanol, Casamino acids, peptone and $\mathrm{H}_{2}+\mathrm{CO}_{2}$. Sulfate, thiosulfate, sulfite, nitrate and nitrite were not used as terminal electron acceptors. Strain MET-B ${ }^{\mathrm{T}}$ could grow with chloramphenicol, kanamycin or vancomycin (at $10 \mu \mathrm{g} \mathrm{ml}^{-1}$ in each case) or $50 \mu \mathrm{g}$ rifampicin $\mathrm{ml}^{-1}$.

Members of the order Thermotogales, comprising anaerobic, rod-shaped micro-organisms whose cells are surrounded by sheath-like structures (like strain MET- ${ }^{\mathrm{T}}$ ), are recognized as common inhabitants of deep, hot oil reservoirs located in marine or continental ecosystems (Magot et al., 2000; Ollivier \& Cayol, 2005). Of these, it is noteworthy that species belonging to the genera Geotoga or Petrotoga have been isolated only from petroleum environments, indicating that they might be indigenous to moderately deep and hot oil reservoirs (Ollivier \& Cayol, 2005). The genus Petrotoga comprises five species, each of which is considered as being moderately thermophilic to thermophilic (i.e. with an optimum temperature for growth between 55 and $60{ }^{\circ} \mathrm{C}$ ) heterotrophs growing in habitats covering a broad range of salt concentrations ( $0.5-20 \%$, depending on the species). In addition, they have DNA G $+\mathrm{C}$ contents ranging from 34 to $36.1 \mathrm{~mol} \%$. Culture enrichments that we performed to recover heterotrophic nitrate-reducing micro-organisms from an offshore oil well in Congo (West Africa) led to the isolation of strain MET- $\mathrm{B}^{\mathrm{T}}$, which was able to use glucose as an energy source, but unable to use nitrate as a terminal electron acceptor. This strain showed phenotypic characteristics and genomic properties (e.g. a DNA G +C content of $34.6 \mathrm{~mol} \%$ ) that were consistent with its placement within the genus Petrotoga rather than the genus Geotoga. Moreover, small-subunit rRNA gene analysis based on 1248 unambiguous nucleotides confirmed that strain MET- $\mathrm{B}^{\mathrm{T}}$ should be considered as a member of the genus Petrotoga, its closest phylogenetic relatives being the type strains of $P$. miotherma (Davey et al., 1993), P. olearia (L'Haridon et al., 2002), P. mexicana (Miranda-Tello et al., 2004) and P. sibirica (L'Haridon et al., 2002), which showed sequence similarities of 99.7, 98.8, 99.0 and $98.5 \%$, respectively (Fig. 1). P. sibirica clearly differs from our isolate and the Petrotoga species cited above as it does not grow at $60^{\circ} \mathrm{C}$ and does not use the same range of substrates (Table 1). Moreover, despite the existence of close phylogenetic relationships between strain MET-B ${ }^{\mathrm{T}}$ and $P$. miotherma, $P$. olearia and $P$. mexicana, a DNA-DNA hybridization analysis revealed relatedness values of only $41.9,25.9$ and $31.1 \%$, respectively, with respect to the type strains of these species. Therefore, according to the criteria of Wayne et al. (1987), strain MET- $\mathrm{B}^{\mathrm{T}}$ is not related to these bacteria at the species level and should be considered as a novel species within the genus Petrotoga. In contrast to $P$. miotherma, strain MET- $\mathrm{B}^{\mathrm{T}}$ fermented xylan and did not produce ethanol from sugar metabolism, but produced lactate (Table 1). Strain MET-B ${ }^{\mathrm{T}}$ differed from $P$. olearia by the absence of motility, by not using peptone and by fermenting galactose (Table 1). Phenotypic differences were also observed between $P$. mexicana and strain MET- $\mathrm{B}^{\mathrm{T}}$, as the latter did not use thiosulfate as a terminal electron acceptor (Table 1). Finally, the optimum $\mathrm{NaCl}$

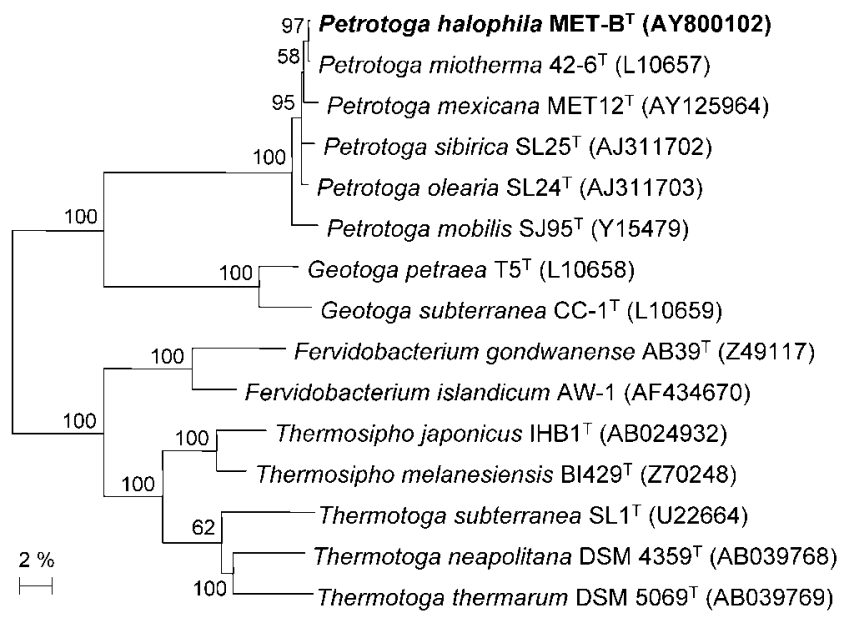

Fig. 1. Phylogenetic dendrogram, based on small-subunit rRNA gene sequence data, indicating the position of strain MET-B with respect to all known species of the family Thermotogaceae. Bootstrap values above $50 \%$ are shown. Bar, 2 nucleotide substitutions per 100 nucleotides. 
Table 1. Characteristics useful for differentiating between strain MET-B ${ }^{\top}$ and phylogenetically related Petrotoga species

Strains: 1, P. miotherma ATCC $51224^{\mathrm{T}}$ (Davey et al., 1993); 2, P. mobilis DSM $10674^{\mathrm{T}}$ (Lien et al., 1998); 3, P. olearia DSM 13574 (L'Haridon et al., 2002); 4, P. sibirica DSM $13575^{\mathrm{T}}$ (L'Haridon et al., 2002); 5, P. mexicana DSM 14811 ${ }^{\mathrm{T}}$ (Miranda-Tello et al., 2004); 6, strain MET-B ${ }^{\mathrm{T}}$ (this study). ND, No data available.

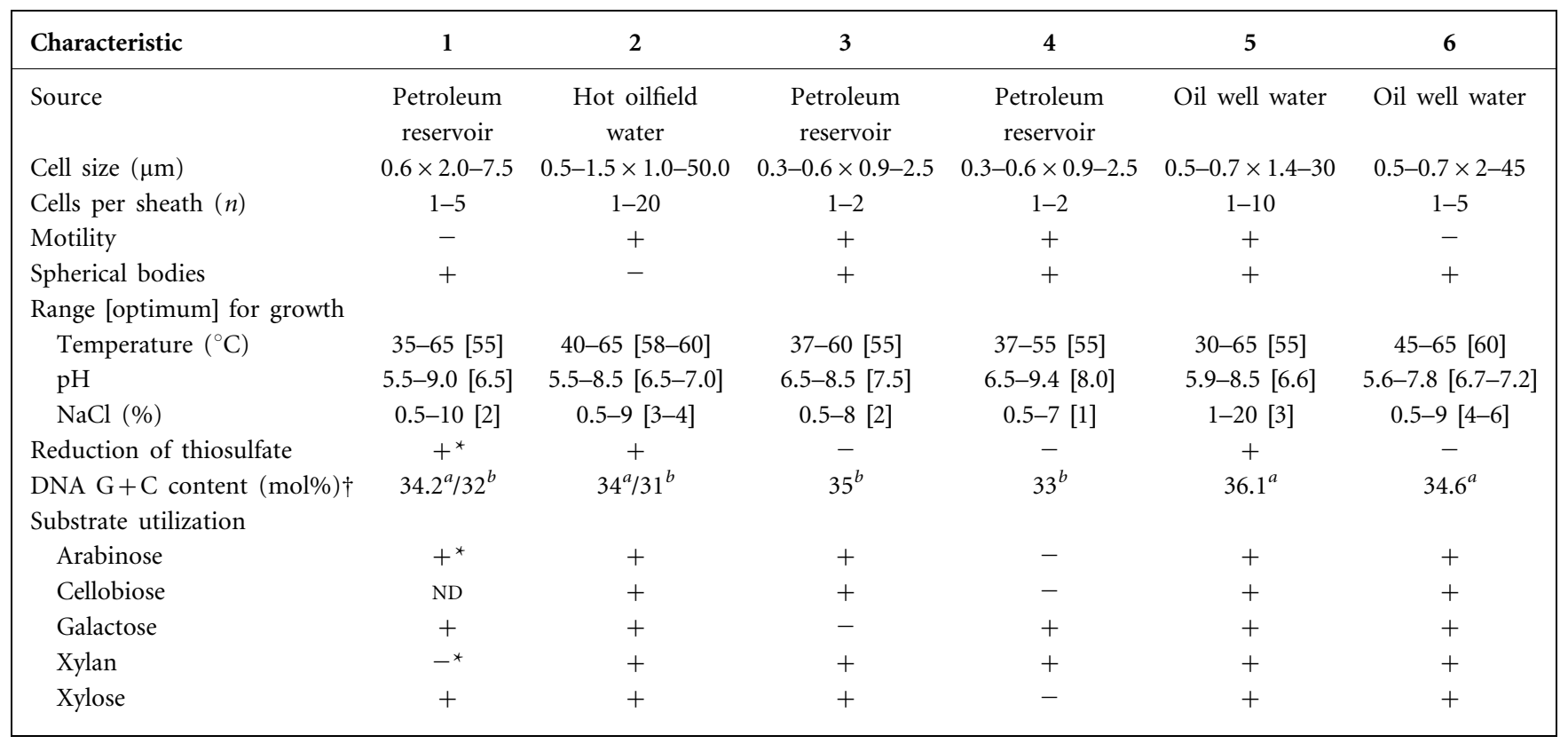

${ }^{\star}$ Data from Lien et al. (1998).

$\dagger$ Determined by: $a$, HPLC method; $b$, thermal denaturation method.

concentration for growth strain of $M E T-\mathrm{B}^{\mathrm{T}}$ was higher (4-6\%) than that of any Petrotoga species, so the novel isolate should be considered as a moderate halophile (Table 1). Therefore, on the basis of the phenotypic and phylogenetic data in this study, strain MET-B ${ }^{\mathrm{T}}$ represents a novel species within the genus Petrotoga, for which the name Petrotoga halophila sp. nov. is proposed.

\section{Description of Petrotoga halophila sp. nov.}

Petrotoga halophila (ha.lo' phi.la. Gr. n. halos salt; Gr. adj. philos loving; N.L. fem. adj. halophila salt-loving).

Cells are rods, $0.5-0.7 \times 2-45 \mu \mathrm{m}$ in size, with an outer sheath-like structure (toga), occurring singly or in sheaths. Electron microscopy of sections of cells exhibits a Gramnegative-type cell wall. Flagella are not observed. No spore formation is detected. Grows at temperatures in the range $45-65^{\circ} \mathrm{C}$, with an optimum at $60{ }^{\circ} \mathrm{C}$. Grows in the presence of $\mathrm{NaCl}$ at concentrations ranging from 5 to $90 \mathrm{~g} \mathrm{l}^{-1}$, with an optimum at 40-60 $\mathrm{g} \mathrm{l}^{-1}$. The optimum $\mathrm{pH}$ for growth is 6.7-7.2, but growth occurs between $\mathrm{pH} 5.6$ and 7.8. Ferments D-arabinose, cellobiose, fructose, galactose, glucose, lactose, maltose, rhamnose, ribose, starch, sucrose, xylose, xylan and pyruvate. Under anaerobic conditions, glucose is fermented into acetate, lactate, $\mathrm{L}$-alanine, $\mathrm{H}_{2}$ and $\mathrm{CO}_{2}$. No L-alanine is produced in the presence of elemental sulfur as the terminal electron acceptor. Acetate, fumarate, succinate, mannose, raffinose, methanol, Casamino acids, peptone and $\mathrm{H}_{2}$ are not used. Elemental sulfur is used as a terminal electron acceptor, but sulfate, sulfite, thiosulfate, fumarate, nitrate and nitrite are not. Grows with chloramphenicol, kanamycin and vancomycin (each at $10 \mu \mathrm{g} \mathrm{ml}^{-1}$ ) and with $50 \mu \mathrm{g}$ rifampicin $\mathrm{ml}^{-1}$. The DNA G $+\mathrm{C}$ content is $34.6 \mathrm{~mol} \%$ (HPLC).

The type strain, MET-B ${ }^{\mathrm{T}}$ ( = DSM $16923^{\mathrm{T}}=$ CCUG $50214^{\mathrm{T}}$ ), was isolated from an oil well in Congo, West Africa.

\section{Acknowledgements}

We acknowledge financial support (to E. M.-T.) from Consejo Nacional de Ciencia y Tecnología, Secretaría de Educación Pública and Société Française d'Exportation des Ressources Éducatives. We are grateful to Jean-Luc Cayol for careful revision of the manuscript.

\section{References}

Balch, W. E., Fox, G. E., Magrum, R. J. \& Wolfe, R. S. (1979). Methanogens: reevaluation of a unique biological group. Microbiol Rev 43, 260-296.

Benson, D., Boguski, M. S., Lipman, D. J., Ostell, J., Ouellette, B. F., Rapp, B. A. \& Wheeler, D. L. (1999). GenBank. Nucleic Acids Res 27, 12-17.

Connan, J., Lacrampe-Couloume, G. \& Magot, M. (1996). Origin of gases in reservoirs. In Proceedings of the 1995 Gas Research 
Conference, vol. 1, pp. 21-61. Edited by D. A. Dolenc. Rockville, MD: Government Institutes.

Cord-Ruwisch, R. (1985). A quick method for the determination of dissolved and precipitated sulfides in cultures of sulfate-reducing bacteria. J Microbiol Methods 4, 33-36.

Davey, M. E., Wood, W. A., Key, R., Nakamura, K. \& Stahl, D. A. (1993). Isolation of three species of Geotoga and Petrotoga: two new genera, representing a new lineage in the bacterial line of descent distantly related to the "Thermotogales". Syst Appl Microbiol 16, 191-200.

Fardeau, M.-L., Ollivier, B., Patel, B. K. C., Magot, M., Thomas, P., Rimbault, A., Rocchiccioli, F. \& Garcia, J.-L. (1997). Thermotoga hypogea sp. nov., a xylanolytic, thermophilic bacterium from an oilproducing well. Int J Syst Bacteriol 47, 1013-1019.

Felsenstein, J. (1985). Confidence limits on phylogenies: an approach using the bootstrap. Evolution 39, 783-791.

Hall, T. A. (1999). BioEdit: a user-friendly biological sequence alignment editor and analysis program for Windows 95/98/NT. Nucleic Acids Symp Ser 41, 95-98.

Hungate, R. E. (1969). A roll-tube method for the cultivation of strict anaerobes. Methods Microbiol 3B, 117-132.

Jukes, T. H. \& Cantor, C. R. (1969). Evolution of protein molecules. In Mammalian Protein Metabolism, pp. 21-232. Edited by H. N. Munro. New York: Academic Press.

L'Haridon, S., Miroshnichenko, M. L., Hippe, H., Fardeau, M. L., Bonch-Osmolovskaya, E. A., Stackebrandt, E. \& Jeanthon, C. (2002). Petrotoga olearia sp. nov. and Petrotoga sibirica sp. nov., two thermophilic bacteria isolated from a continental petroleum reservoir in Western Siberia. Int J Syst Evol Microbiol 52, 1715-1722.

Lien, T., Madsen, M., Rainey, F. A. \& Birkeland, N. K. (1998). Petrotoga mobilis sp. nov., from a North Sea oil-production well. Int J Syst Bacteriol 48, 1007-1013.

Magot, M., Ollivier, B. \& Patel, B. K. C. (2000). Microbiology of petroleum reservoirs. Antonie van Leeuwenhoek 77, 103-116.

Maidak, B. L., Cole, J. R., Lilburn, T. G., Parker, C. T., Jr, Saxman, P. R., Farris, R. J., Garrity, G. M., Olsen, G. J., Schmidt, T. M. \&
Tiedje, J. M. (2001). The RDP-II (Ribosomal Database Project). Nucleic Acids Res 29, 173-174.

Mesbah, M., Premachandran, U. \& Whitman, W. B. (1989). Precise measurement of the $\mathrm{G}+\mathrm{C}$ content of deoxyribonucleic acid by high-performance liquid chromatography. Int J Syst Bacteriol 39, 159-167.

Miranda-Tello, E., Fardeau, M.-L., Thomas, P., Ramirez, F., Casalot, L., Cayol, J.-L., Garcia, J.-L. \& Ollivier, B. (2004). Petrotoga mexicana sp. nov., a novel thermophilic, anaerobic and xylanolytic bacterium isolated from an oil-producing well in the Gulf of Mexico. Int J Syst Evol Microbiol 54, 169-174.

Ollivier, B. \& Cayol, J.-L. (2005). The fermentative, iron-reducing, and nitrate-reducing microorganisms. In Petroleum Microbiology, pp. 71-88. Edited by B. Ollivier \& M. Magot. Washington, DC: American Society for Microbiology.

Saito, N. \& Nei, M. (1987). The neighbor-joining method: a new method for reconstructing phylogenetic trees. Mol Biol Evol 4, 406-425.

Stetter, K. O., Huber, R., Blöchl, E., Kurr, M., Eden, R. D., Fielder, M., Cash, H. \& Vance, I. (1993). Hyperthermophilic archaea are thriving in deep North Sea and Alaskan oil reservoirs. Nature 365, 743-745.

Thabet, O. B., Fardeau, M.-L., Joulian, C., Thomas, P., Hamdi, M., Garcia, J.-L. \& Ollivier, B. (2004). Clostridium tunisiense sp. nov., a new proteolytic, sulfur-reducing bacterium isolated from an olive mill wastewater contaminated by phosphogypse. Anaerobe 10, 185-190.

Van de Peer, Y. \& De Wachter, R. (1994). TREECON for Windows: a software package for the construction and drawing of evolutionary trees for the Microsoft Windows environment. Comput Appl Biosci 10, 569-570.

Wayne, L. G., Brenner, D. J., Colwell, R. R., Grimont, P. A. D., Kandler, O., Krichevsky, M. I., Moore, L. H., Moore, W. E. C., Murray, R. G. E. \& other authors (1987). International Committee on Systematic Bacteriology. Report of the ad hoc committee on reconciliation of approaches to bacterial systematics. Int $J$ Syst Bacteriol 37, 463-464. 